\title{
Apresentação
}

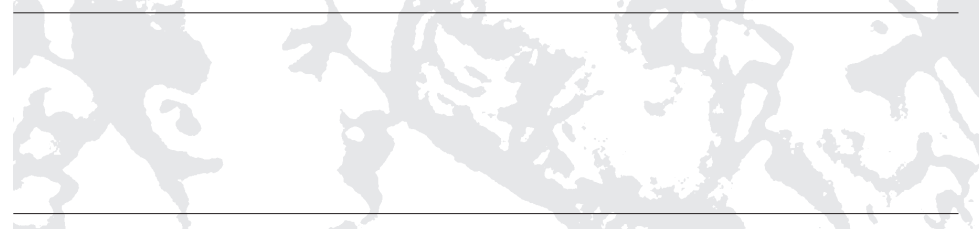

LILIA K. MORITZ SCHWARCZE HELOISA MARIA MURGEL STARLING

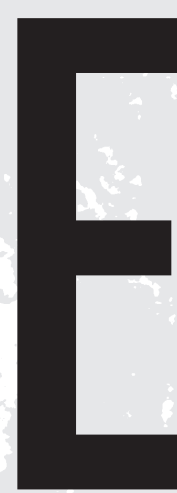

\section{LILIA K. MORITZ}

\section{SCHWARCZ}

é professora do Departamento de Antropologia da USP e autora de, entre outros, Símbolos e Rituais da Monarquia Brasileira (Jorge Zahar).

\section{HELOISA MARIA} MURGEL STARLING

é professora do Departamento de História da UFMG. m um país como o Brasil, que não conheceu uma experiência política capaz de ser legitimamente chamada de republicana, o que vem a ser a República? Para responder à indagação, a realização deste Dossiê exigiu o engate de três percursos. $\bigcirc$ primeiro buscou vasculhar as origens da tradição do republicanismo de forma ampla; o segundo registrou a formação de matrizes dessa tradição entre nós; o terceiro explorou as condições de construção histórica e política do experimento republicano no país.

O retorno da reflexão contemporânea ao fio mais original e resistente do republicanismo, executado no primeiro bloco dos artigos, tem por objetivo identificar conceitos e questões próprios à tradição que podem servir a dois propósitos: de um lado, trazer à tona elementos conceituais pertinentes ao exame da natureza das sociedades democráticas no contexto atual; de outro lado, fornecer elementos que auxiliem na interpretação da realidade específica de uma república, como a brasileira, que precisa ampliar o acesso aos frutos sociais gerados pela introdução da democracia política no país.

Dessa maneira, esses primeiros ensaios são voltados para explorar o perfil de uma tradição que nos alcança até o presente. Oferecem uma investigação sobre os traços de uma compreensão original da vida pública, presente no período do chamado Humanismo Cívico; ou sobre a pertinência da trajetória da idéia de pátria para a construção da comunidade política; ou, ainda, sobre os limites da famosa contraposição entre liberdade negativa e liberdade positiva para se pensar problemas complexos como o das virtudes cívicas, da participação política, da identidade constitucional ou o do patriotismo.

A idéia do resgate a certos temas e aspectos do pensamento republicano próprios à imaginação política e social brasileira dos séculos $X V I I I, X I X$ e $X X$, presente no segundo bloco de artigos, sugere que o pensamento republicano chegou até nós por duas vias: a primeira é a do republicanismo anglosaxão que, pela influência dos radicais e federalistas americanos, se fez presente, por exemplo, no final do Setecentos mineiro ou nas discussões sobre os destinos do Império, pela voz de personagens como Rebouças, Ottoni, Nabuco. A segunda via, de influência francesa, nos liga tanto à tradição jacobina quanto ao positivismo do século XIX, e teve influência decisiva na definição da forma política assumida pela República entre nós.

Por fim, o último bloco de artigos indica as condições históricas de retração do republicanismo no Brasil, e 


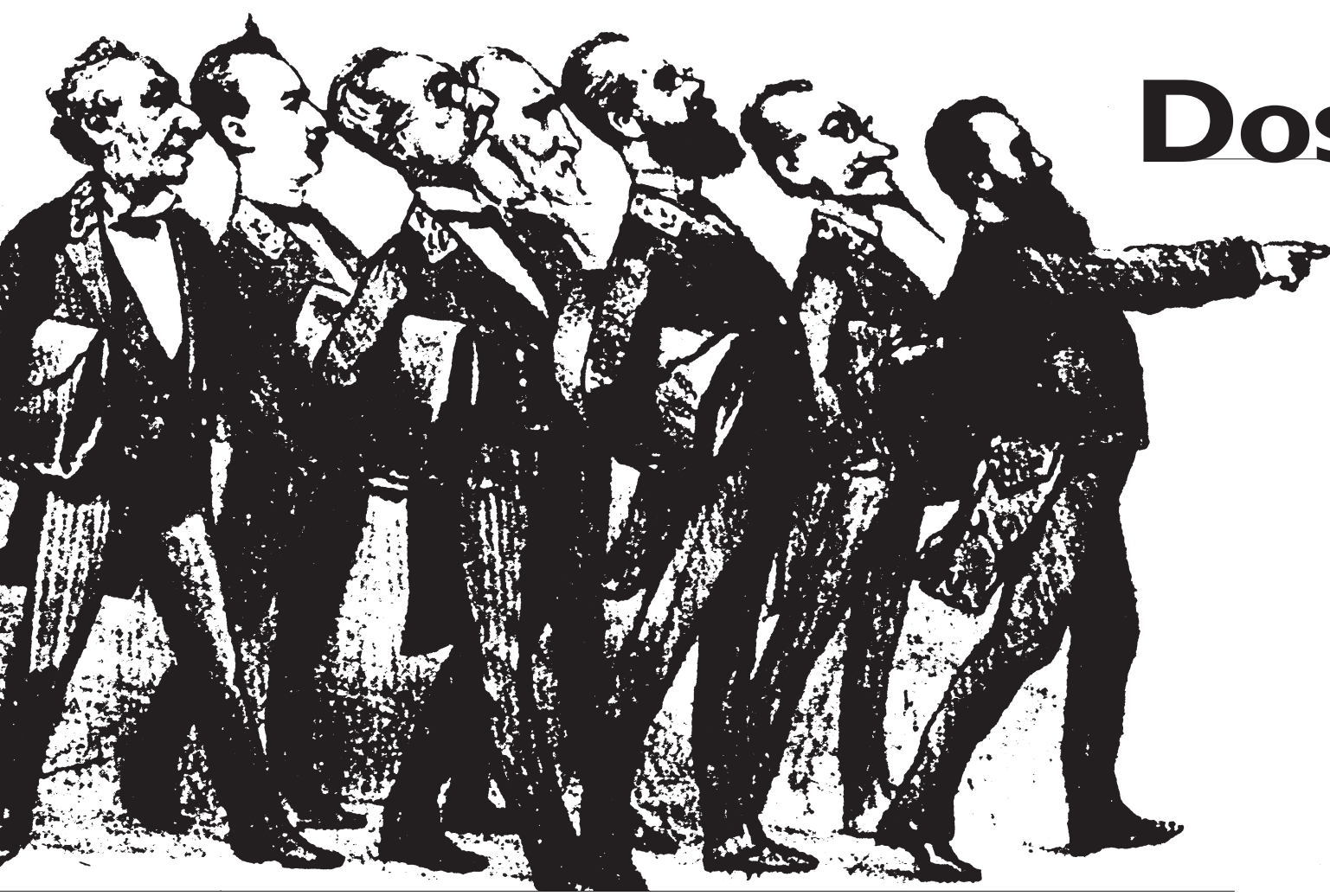

explora as possibilidades de recuperação de alguns de seus traços característicos, em especial, sua capacidade de ampliar os mecanismos de passagem à vida política dando nova figura ao status de cidadão e aos direitos de cidadania. Explora ainda diferentes aspectos e condições dessa nossa maneira de falar de República e de assim entendêla. Em uma construção política republicana como a brasileira, que emergiu em 1889 sem a vocação de incorporação da sociedade, formas políticas muito autoritárias foram trazidas ao moderno pela República. Isso ocorreu, por exemplo, através de um sistema de poder oligárquico capaz de gerenciar suas disputas internas e deixar o povo de fora da sociedade política; ou então pelos impasses nas condições de modernização e alargamento do pacto republicano; ou, ainda, pelas dificul- dades encontradas para definição dos modos de agregação e uso do bem público. Assim, a construção histórica do experimento republicano no país, analisada pelo terceiro bloco de artigos, permite identificar alguns dos obstáculos encontrados pelo Brasil contemporâneo para completar seu ingresso na modernidade política.

Como se poderá notar, não há a intenção de engessar a discussão ou de torná-la imune a uma reflexão sobre a temporalidade. Muito pelo contrário, nossa "moderna tradição republicana" vem "negociando" matrizes que lhe são anteriores, relidas em uma chave que, se não é totalmente original, fala de uma experiência sem dúvida particular.

Nesse sentido, a variedade de artigos, enfoques e perspectivas faz deste volume de textos um verdadeiro dossier de idéias e possibilidades.
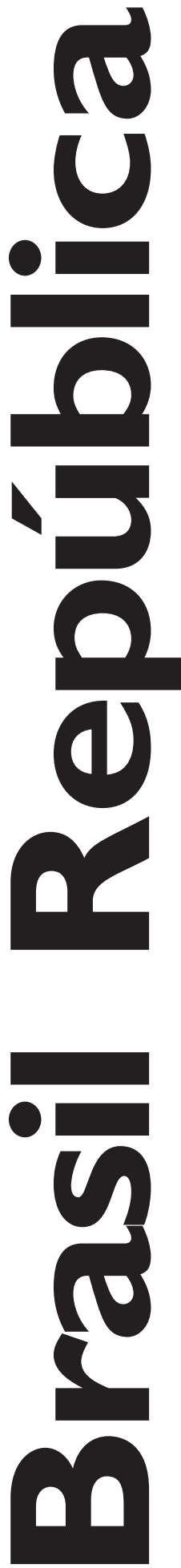